\title{
Analysis of Air Traffic Density using GIS, Case Study: Jakarta-Surabaya
}

\author{
Ratih Sekartadji ${ }^{1, a}$, Ervina Ahyudanari ${ }^{1, b}$, Lalu Muhamad Jaelani ${ }^{2, c}$ \\ ${ }^{1}$ Postgraduate Program of Civil Engineering, \\ Institute Teknologi Sepuluh Nopember, Surabaya, Indonesia \\ ${ }^{2}$ Dept. Of Geomatics Engineering, \\ Institute Teknologi Sepuluh Nopember, Surabaya, Indonesia
}

"Corresponding author : ratih.sekartadji.its@gmail.com, ${ }^{\mathrm{b}}$ ervina@ce.its.ac.id, ${ }^{\mathrm{c}}$ 1mjaelani@geodesy.its.ac.id

\begin{abstract}
The growth of air transportation is encouraged by high demand to travel fast. Jakarta-Surabaya route is placed as the fourth busiest traffic in the world. This busy route still possible to increase, unless there is an alternative mode of transport to serve the demand of this route. Aircraft flies at a certain flight level that is influenced by the flight distance and the type of aircraft. Jakarta-Surabaya route is served by aircrafts with different types. This means that some flight levels between Jakarta and Surabaya are occupied by these serving aircrafts. On the other hand, at the same flight level, there will be some other planes for other routes. This research attempts to picture the density of the flight level of Jakarta-Surabaya route. The density value will be useful to predict the air quality and the available air space to add the flight frequencies. Data collection of Jakarta-Surabaya flights was aimed to identify the occupied flight level by this route. For other routes that may be crossed or in line with the Jakarta-Surabaya route, are derived from International Civil Aviation (ICAO) Charts. Incorporating the route volume resulting the traffic derivation from the charts and scheduled flight into the network attribute of GIS. Data histories of the flight density from ICAO Charts are used to predict the future density utilizing the GIS. The horizon year for this research is year 2030 where some airports will be improved into higher level airport groups, according to PM No. 69 year 2013.
\end{abstract}

Keywords: air traffic, flight level, route, GIS

\section{INTRODUCTION}

Air transport is a mode of transportation that is currently growing rapidly. This is because air transportation mode is the most rapid and efficient mode compared to other modes of transportation. The growth of air transportation is driven by the high demand for travel quickly. [4].

Data from the Centre for Aviation in 2014 states that the frequency of flights from Soekarno-Hatta International Airport Jakarta to Juanda International Airport Surabaya was ranked fourth in the world in October 2014. [1] Total flight frequency of the route exceeds the frequency of flights at Los Angeles International Airport in the United States and Tokyo Haneda Airport in Japan. From the Airport Council International data at the end of 2014 the Soekarno-Hatta Airport in Jakarta is eleventh of the number of passengers departing, arriving and transiting at the airport.[1]

Indonesia is also the busiest airport in terms of domestic and international flights. Jakarta-Surabaya route is still possible to increase, unless there is an alternative mode of transportation to serve the request of this route.

Table 1 shows the flight frequency for the Jakarta Surabaya route of 819 flights in a week in the second week of October 2014 according to the Center for Aviation data. While the data collection route Jakarta Jakarta route is obtained from the International Civil Aviation (ICAO) Flow Chart 2015 latest OAG data. [2]
From these data are also obtained other routes that may be through the route Jakarta-Surabaya, or other routes that some flights through the area in the route JakartaSurabaya.

A Geographic Information System (GIS) is a computer system for the input, manipulation, store and output of digital spatial data. In a more broad definition it is a digital system for the acquisition, management, analysis and visualization of spatial data for the purpose of planning, administering and monitoring the natural and socioeconomic environment. It represents a digital model of geography in its widest sense. [3].

A GIS consists of a system for data input in vector form, in raster form and in alphanumeric form; a central processing unit (CPU) containing the programs for data processing, data storage and data analysis and of facilities for visualization; and hard copy out put of the data. In a broad sense, a GIS includes the data, which are managed by an administration or a unit conducting a project for the purpose of data inventory, data analysis and data presentation for administrative support or for decision support. [3].

The International Civil Aviation Organization (ICAO) is a UN specialized agency, created in 1944 upon the signing of the Convention on International Civil Aviation (Chicago Convention). ICAO works with the Convention's 191 Member States and global aviation organizations to develop international Standards and Recommended Practices (SARPs) which States reference when developing their legally-enforceable national civil aviation regulations. The ICAO GIS Services is an electronic database based on the geographical Flight 
Information Region (FIR's) from around the world. This The Figure 1 above shows traffic flows in Indonesia in Information is gathered from each state from regional 2015. [2]. offices and approuved amendments dating back to 1947.

Tabel 1

Frequency of 10 Highest Flight Routes in the World

\begin{tabular}{|c|c|c|c|}
\hline Rank & Origin & Destination & $\begin{array}{l}\text { Total } \\
\text { Frequencies }\end{array}$ \\
\hline 1 & CJU Jeju Airport & $\begin{array}{ll}\text { GMP } & \begin{array}{l}\text { Seoul Gimpo International } \\
\text { Airport }\end{array} \\
\end{array}$ & 1.087 \\
\hline 2 & $\begin{array}{l}\text { Sydney Kingsford Smith } \\
\text { Airport }\end{array}$ & $\begin{array}{ll}\text { MEL } & \begin{array}{l}\text { Melbourne Tullamarine } \\
\text { Airport }\end{array} \\
\end{array}$ & 1.035 \\
\hline 3 & $\begin{array}{ll}\text { SDU } & \begin{array}{l}\text { Rio de Janeiro Santos } \\
\text { Dumont Airport }\end{array}\end{array}$ & CGH Sao Paulo Congohas Airport & 934 \\
\hline 4 & $\begin{array}{l}\text { CGK Jakarta Soekarno-Hatta } \\
\text { International Airport }\end{array}$ & $\begin{array}{ll}\text { SUB } & \begin{array}{l}\text { Surabaya Juanda } \\
\text { International Airport }\end{array}\end{array}$ & 819 \\
\hline 5 & DEL $\begin{array}{l}\text { Delhi Indira Gandhi } \\
\text { International Airport }\end{array}$ & $\begin{array}{l}\text { BOM Mumbai Chhatrapati Shivaji } \\
\text { International Airport }\end{array}$ & 783 \\
\hline 6 & LAX $\begin{array}{l}\text { Los Angeles International } \\
\text { Airport }\end{array}$ & $\begin{array}{ll}\text { SFO } & \begin{array}{l}\text { San Francisco International } \\
\text { Airport }\end{array}\end{array}$ & 774 \\
\hline 7 & HND Tokyo Haneda Airport & CTS Sapporo Chitose Airport & 760 \\
\hline 8 & FUK Fukuoka Airport & HND Tokyo Haneda Airport & 758 \\
\hline 9 & $\begin{array}{ll}\text { SYD } & \begin{array}{l}\text { Sydney Kingsford Smith } \\
\text { Airport }\end{array} \\
\end{array}$ & BNE Brisbane Airport & 651 \\
\hline 10 & $\begin{array}{c}\text { HKG } \begin{array}{l}\text { Hong Kong International } \\
\text { Airport }\end{array} \\
\end{array}$ & $\begin{array}{ll}\text { TPE } & \begin{array}{l}\text { Taipei Taoyuan International } \\
\text { Airport }\end{array} \\
\end{array}$ & 622 \\
\hline
\end{tabular}

Source: Centre for Aviation, 2014

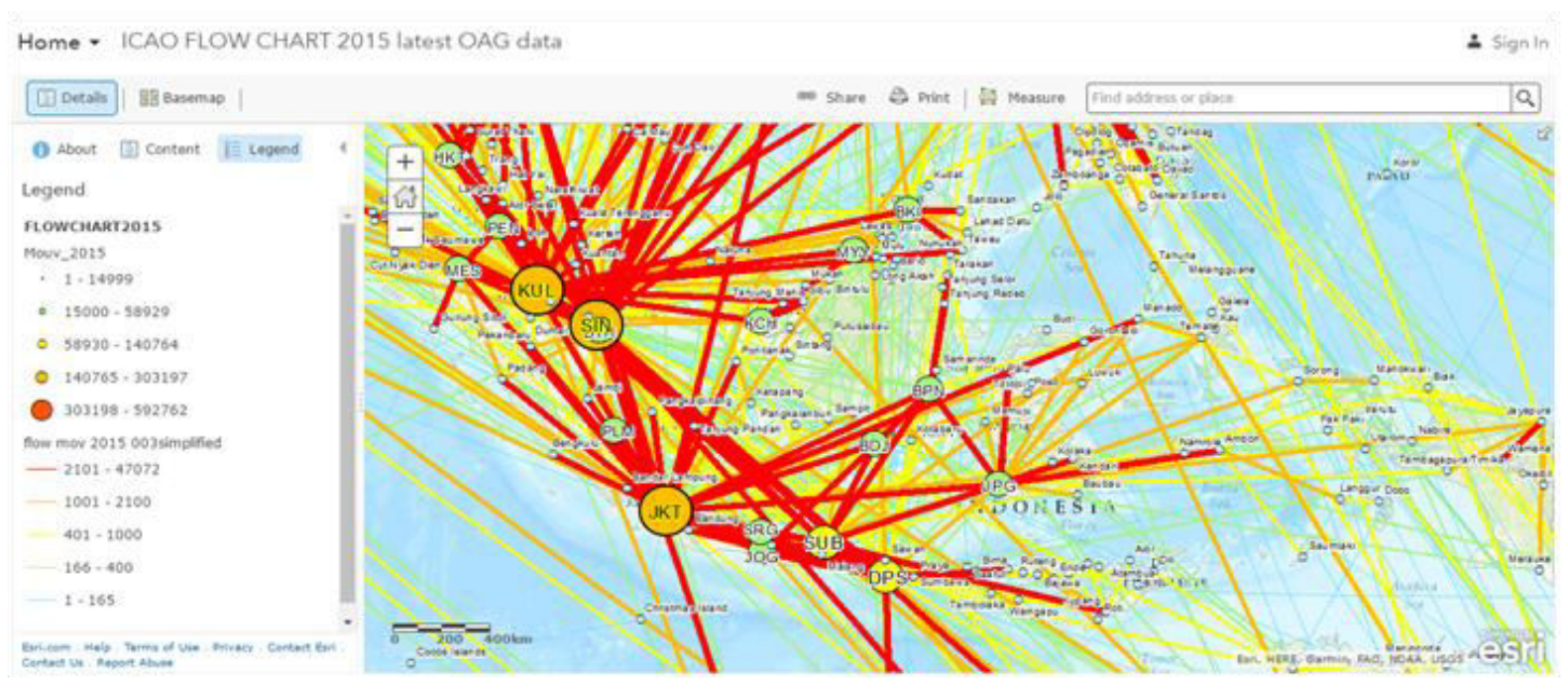

Figure 1. ArcGis Map for Indonesia Traffic Flow 2015 (source: ICAO, 2015)

Figure 1 illustrates the flight routes present in Indonesia both domestic and international flights during 2015. From the picture below, the blue line is thin for a flow of 1 to 165 flights. The green line is slightly thicker for the flow of 166 to 400 flights. And so on for yellow lines for traffic flow of 401 to 1,000 flights, orange lines for traffic flow of 1,001 to 2100 flights and red lines for traffic flow of 2,101 to 47,072 flights each of which lines thicker, representing the greater the traffic flow that occurs on the route. For domestic flights in Indonesia can be seen that the route is the thickest and red line is the route JakartaSurabaya. For more details can be seen in Figure 2 below. Figure 2 illustrates the Jakarta-Surabaya route where there are Jakarta-Semarang route, Semarang-Surabaya route, Bandung-Surabaya route and Bandung-Semarang route. Similarly, routes that partly route through JakartaSurabaya route are: Jakarta-Lombok route, Jakarta- 
Kupang route, Jakarta-Denpasar route and Jakarta-Malang route.

Each line contains a sum of traffic flows of that route in each year. Collecting data by searching routes that pass through Jakarta to Surabaya and summed up for each year.

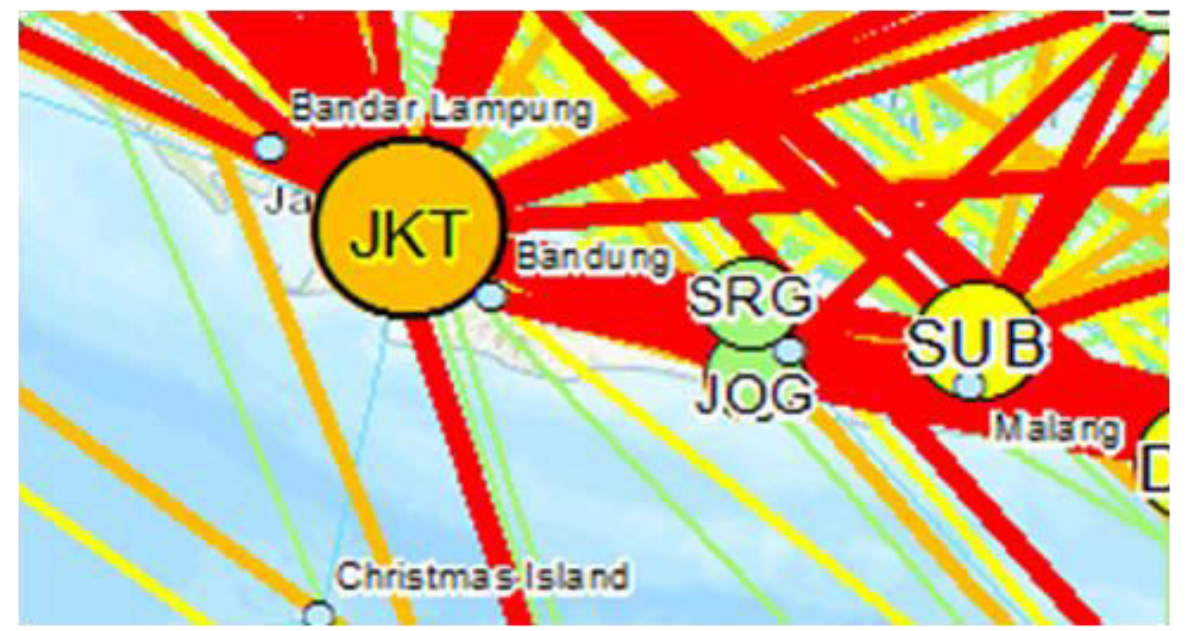

Figure 2. ArcGis Map for Jakarta-Surabaya Route Traffic Flow 2015 (source: ICAO, 2015)

\section{METHOD}

The aircraft flies at a certain flight level that is affected by the flight distance and the type of aircraft.

1. Flight Distance

In aviation, the flight length is defined as the distance of a flight. The actual flight length is the length of the track flown across the ground in practice, which is usually longer than the ideal great-circle and is influenced by a number of factors such as the need to avoid bad weather, wind direction and speed, fuel economy, navigational restrictions and other requirements. Flight length of Jakarta to Surabaya can be seen in Figure 3 below and distance of flights can be seen in Table 2 below.

\section{Type of Aircraft}

The type of aircraft for Jakarta Surabaya route that can be seen on Table 3 below, consist from Airbus and Boeing.

The route from Jakarta to Surabaya is served by airplanes of various types. This means that some flight levels between Jakarta and Surabaya are occupied by this aircraft. On the other hand, at the same flight level, there will be several other aircraft for other routes. This research tries to describe the flight density of JakartaSurabaya route. Density values will be useful for predicting air and airspace quality available to increase flight frequency.

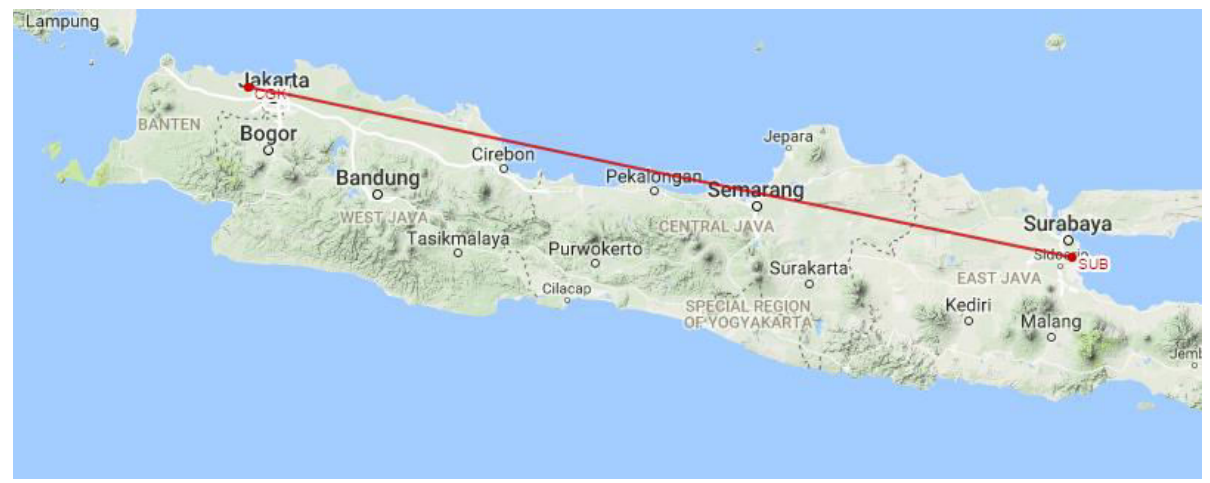

Figure 3. Flight Length of Jakarta to Surabaya (source: Great Circle Mapper, 2017). 
Table 2. Distance of A Flights

\begin{tabular}{llll}
\hline No & Departure & Arrival & $\begin{array}{c}\text { Distance } \\
(\mathrm{km})\end{array}$ \\
\hline 1 & JKT & SUB & 692 \\
& SUB & JKT & \\
2 & SUB & SRG & 270 \\
& SRG & SUB & \\
3 & SUB & BDO & 578 \\
& BDO & SUB & \\
4 & JKT & SRG & 422 \\
& SRG & JKT & \\
5 & JKT & BIL & 1101 \\
& BIL & JKT & \\
6 & JKT & MLG & 698 \\
& MLG & JKT & \\
7 & JKT & KOE & 1927 \\
& KOE & JKT & \\
8 & JKT & DPS & 983 \\
& DPS & JKT & \\
9 & DPS & SMG & 564 \\
& SMG & DPS & \\
10 & BDO & SMG & 309 \\
& SMG & BDO & \\
\hline \multirow{4}{*}{5} & Source: Great & Circle Mapper, 2017
\end{tabular}

The flight data collection of Jakarta-Surabaya aims to identify the flight rate occupied by this route. For other routes that may be passed or in accordance with the Jakarta-Surabaya route, come from the International Civil Aviation (ICAO) Charts as can be seen in table 4 below.

From the table 4 below, total traffic flows for Jakarta to Surabaya route in each year from 2012 until 2015 are presented. It shows that the traffic flows grow about 3,000 until 5,000 flights per year.
The flight data collection of Jakarta-Surabaya aims to identify the flight rate occupied by this route. For other routes that may be passed or in accordance with the Jakarta-Surabaya route, come from the International Civil Aviation (ICAO) Charts as can be seen in table 4 above. From the table 4, total traffic flows for Jakarta to Surabaya route in each year from 2012 until 2015 are presented. It shows that the traffic flows grow about 3,000 until 5,000 flights per year. Figure 4 shows a graphic of traffic flows between Jakarta and Surabaya on two directions.

Table 3. Aircraft Types for Surabaya-Jakarta Route

\begin{tabular}{cccc}
\hline Name & Manufacturer & Type & IATA \\
\hline A320-100 & Airbus & Airliner & 320 \\
A330-200 & Airbus & Airliner & 332 \\
A330-300 & Airbus & Airliner & 333 \\
$737-300$ & Boeing & Airliner & 733 \\
$737-800$ & Boeing & Airliner & 738 \\
$737-900$ & Boeing & Airliner & 739 \\
\hline \multicolumn{4}{c}{ Source: Global Aviation, 2017 }
\end{tabular}


Table 4. Traffic Flows in Jakarta-Surabaya Route from 2012-2015

\begin{tabular}{|c|c|c|c|c|c|c|}
\hline No & Departure & Arrival & 2012 & 2013 & 2014 & 2015 \\
\hline \multirow{2}{*}{1} & JKT & SUB & 14.759 & 19.813 & 20.684 & 21.553 \\
\hline & SUB & JKT & 15.780 & 20.392 & 21.045 & 21.553 \\
\hline \multirow{2}{*}{2} & SUB & SRG & 1.784 & 2.407 & 2.081 & 2.867 \\
\hline & SRG & SUB & 1.969 & 2.652 & 2.375 & 2.867 \\
\hline \multirow{2}{*}{3} & SUB & BDO & 1.947 & 1.592 & 1.712 & 1.796 \\
\hline & BDO & SUB & 1.947 & 1.592 & 1.712 & 1.796 \\
\hline \multirow{2}{*}{4} & JKT & SRG & 9.256 & 8.930 & 8.993 & 8.492 \\
\hline & SRG & JKT & 9.256 & 8.930 & 8.993 & 8.492 \\
\hline \multirow{2}{*}{5} & JKT & LOP & 2.269 & 2.691 & 2.904 & 3.655 \\
\hline & LOP & JKT & 2.276 & 2.691 & 2.904 & 3.655 \\
\hline \multirow{2}{*}{6} & JKT & MLG & 2.187 & 1.856 & 2.028 & 2.512 \\
\hline & MLG & JKT & 2.187 & 1.856 & 2.028 & 2.512 \\
\hline \multirow{2}{*}{7} & JKT & KOE & 595 & 197 & 89 & 478 \\
\hline & KOE & JKT & 419 & 166 & 89 & 478 \\
\hline \multirow{2}{*}{8} & JKT & DPS & 12.761 & 14.157 & 14.738 & 14.205 \\
\hline & DPS & JKT & 12.933 & 14.153 & 14.719 & 14.205 \\
\hline \multirow{2}{*}{9} & DPS & SMG & 366 & 422 & 728 & 747 \\
\hline & SMG & DPS & 366 & 422 & 728 & 747 \\
\hline \multirow{3}{*}{10} & BDO & SMG & 184 & 230 & 52 & 450 \\
\hline & SMG & BDO & 184 & 230 & 52 & 450 \\
\hline & \multicolumn{2}{|c|}{ TOTAL } & 95.437 & 107.392 & 110.668 & 115.525 \\
\hline
\end{tabular}

Source: ICAO Map ArcGis, 2015

\section{RESULTS AND DISCUSSION}

the underlying relationships between the projectedactivity The most sophisticated and complex technique in airport descriptor and the many variables which affect its change.
demand forecasting is the use of econometric models. There are a wide range of economic, social, market and Trend extrapolation methods do not explicitly examine operational factors which affect aviation.[8]

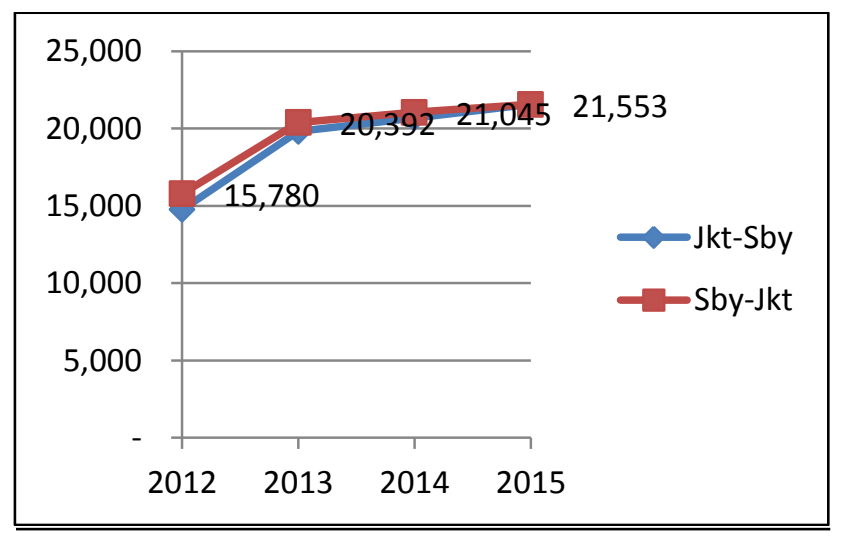

Figure 4. Traffic Flows from Jakarta to Surabaya and Surabaya to Jakarta 
The Third International Conference on Civil Engineering Research (ICCER)

August $1^{\text {st }}-2^{\text {nd }}$ 2017, Surabaya - Indonesia

Home $\quad$ ICAO TRAFFIC FLOW 2030
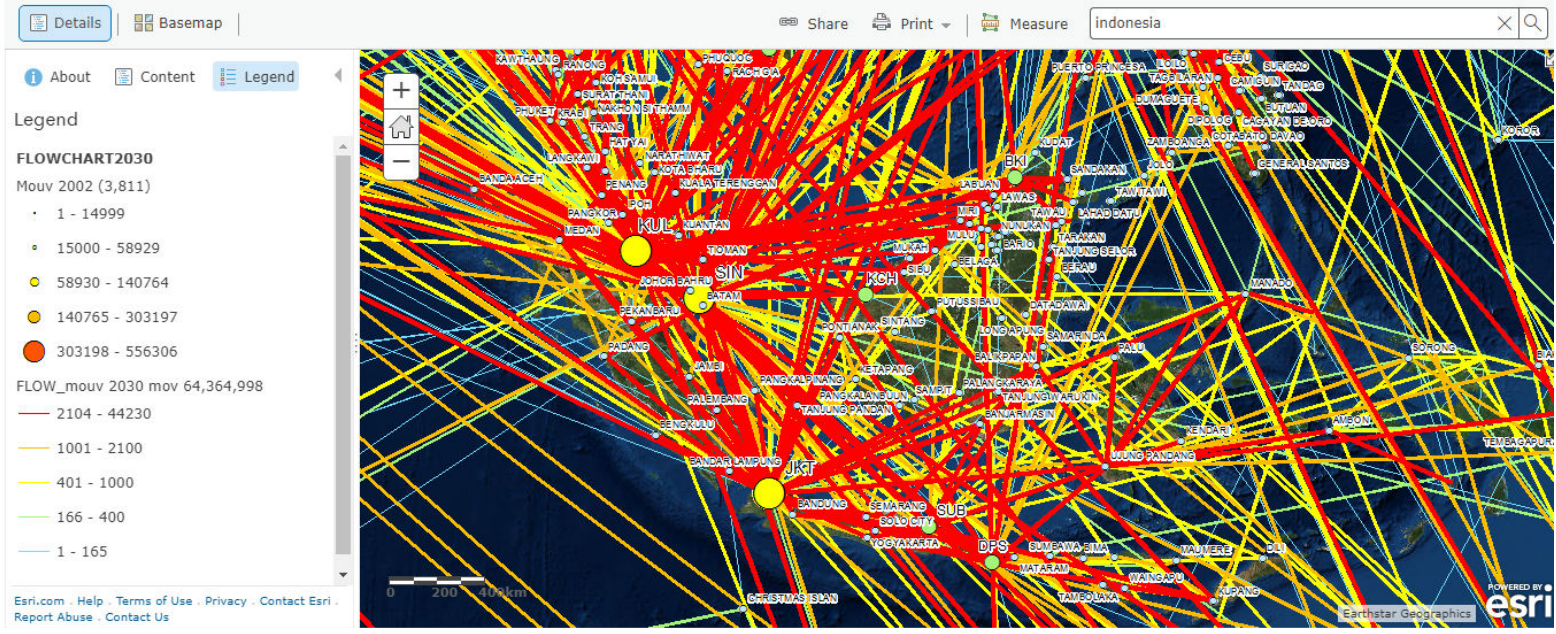

Figure 5. ArcGis Map for Indonesia Routes Forecast of Traffic Flow 2030 (source: ICAO, 2017)

Home ICAO TRAFFIC FLOW 2030
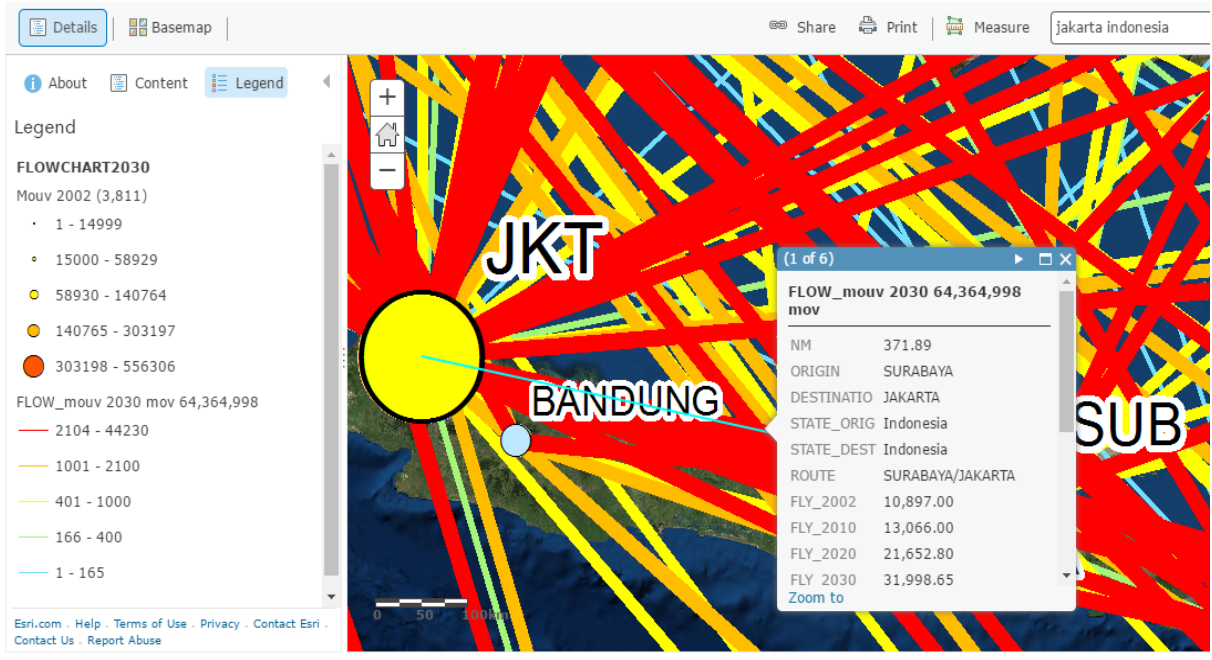

Figure 6 . ArcGis Map for Surabaya-Jakarta Route Forecast of Traffic Flow 2030 (source: ICAO, 2017)

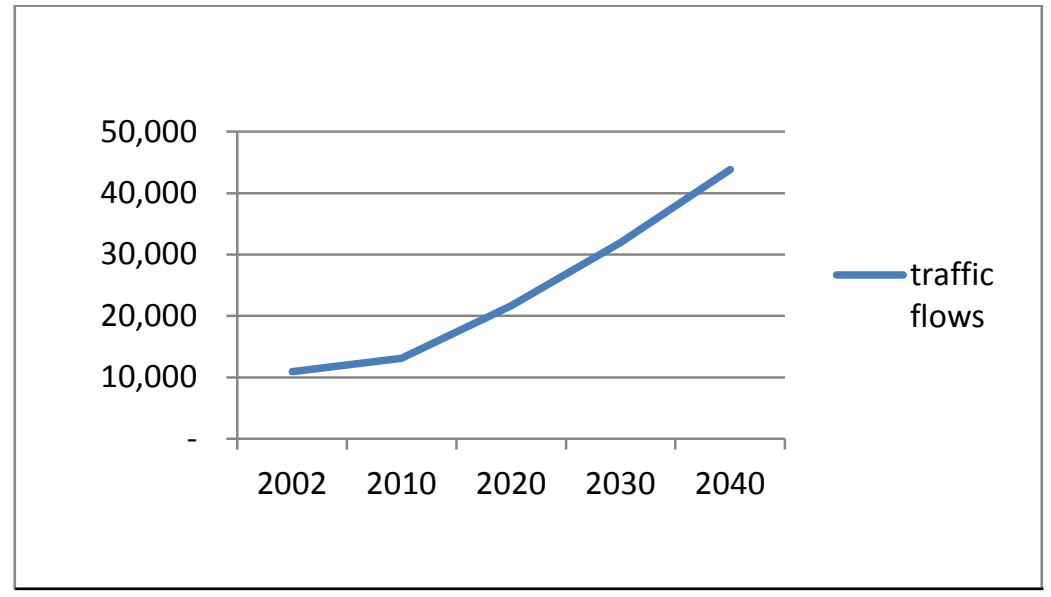

Figure 7. Forecast of Traffic Flows between Jakarta and Surabaya 
Therefore, to properly assess the impact of predicted changes in the other sectors of society upon aviation demand and to investigate the effect of alternative assumpsions on aviation. Econometric models which relate measures of aviation activity to economic and social factors are extremely valuable techniques in forecasting the future.[8].

This study based on the ArcGIS from ICAO and figure 5 above presents forcast for Traffic Flow in 2030 for Indonesia airspace area. Every line can show a number of flights between each city pair. Result of the forecast for traffic flows between Jakarta and Surabaya from ICAO can be seen in figure 6 and 7 above. The time was taken from 2002 until 2040.

To enforce ministerial policy according to PM no. 69 year 2013 article 24 which contents The national master plan of the airport shall be an internal guideline, determination of location, preparation of master plan, development, Operation, and airport development which is concerning to: National spatial plan, regional spatial plan Provincial, district / city spatial plan; Regional socioeconomic potential and development; and Potential natural resources; which is the potential of natural resources that can be utilized in a manner efficiently while maintaining environmental sustainability.

\section{REFERENCES}

[1] International Civil Aviation Organization (ICAO), ICAO Map ArcGis, 2017.

[2] Centre for Aviation (CAPA), 2014.

[3] Gottfried Konecny, "Geoinformation - Remote Sensing, Photometry and Geographic Information System," 2nd edition, Taylor \& Francis, London, 2003, pp. 261-272.

[4] Marcella Sama, Andrea D'Ariano, Paolo D'Ariano, Dario Pacciarelli, "Scheduling models for optimal aircraft traffic control at busy airports: Tardiness, priorities, equity and violations considerations," Omega, Elsevier, 2016.

[5] Great Circle Mapper, 2017, www.greatcirclemapper.com

[6] Global Aviation, 2017, www.aviability.com

[7] Fahrizal, Mochamad Sony, Analisis Pertumbuhan Penggunaan Pesawat terhadap Beban Emisi Karbon Bandar Udara Internasional Juanda, Tugas Akhir, Institut Teknologi Sepuluh Nopember Surabaya, 2016.

[8] Horonjeff, R. McKelvey, F.X., Sproule, W.J., Young, S.B., 2010, Planning and Design of Airports, the 5th edition, The McGraw-Hill, Inc.

[9] PM no.69 year 2013, 2013. 